\title{
Biofuel purification: Coupling experimental and theoretical investigations for an efficient separation of phenol from aromatics by zeolites
}

Ibrahim Khalil ${ }^{1 *}$, Hicham Jabraoui ${ }^{2}$, Sébastien Lebègue ${ }^{2}$, Won June Kim $^{3}$, Luis-Jacobo Aguilera $^{1}$, Karine Thomas ${ }^{1}$, Françoise Maugé ${ }^{1}$, Michael Badawi ${ }^{2 *}$

${ }^{1}$ Laboratoire Catalyse et Spectrochimie, ENSICAEN, Université de Caen Normandie, CNRS, 6 bd du Maréchal Juin, 14050 Caen, France

${ }^{2}$ Laboratoire Physique et Chimie Théoriques (LPCT) UMR 7019 CNRS, Université de Lorraine, F-54000 Nancy, France

${ }^{3}$ Department of Biology and Chemistry, Changwon National University, Changwondaehak-ro 20, Uichang-gu, Changwon-si, Gyeongsangnam-do, South Korea

*Corresponding authors: ibrahim.khalil@ensicaen.fr; michael.badawi@ univ-lorraine.fr

ABSTRACT

The purification of second-generation biofuels is becoming an urgent issue due to the toxicity of the combustion products of residual phenol in these biofuels. The use of solid sorbents such as zeolites appears as a promising solution for ensuring the selective sorption of phenol towards aromatics (the main components of biofuel). In the present work, we have adopted a bottom-up approach for removing phenol from a synthetic biofuel feed containing isooctane, $1 \mathrm{wt} . \%$ phenol, $1 \mathrm{wt} . \% \mathrm{n}$-nonane and $40 \mathrm{wt}$.\% toluene, using faujasitetype $\mathrm{Y}$ zeolites with $\mathrm{Si} / \mathrm{Al}$ ratio $=2.5$. The adsorption modes of the molecules involved have been assessed by comparing theoretical and experimental infrared spectra. In addition, coupling molecular modeling with breakthrough curves has revealed the important role of protons embedded in zeolites for the selective removal of phenol.

Keywords: adsorption, biofuels, phenol adsorption, DFT, DFPT, FT-IR spectroscopy, interaction energies 


\section{Introduction}

The increase in the global energy consumption through the use of fossil fuels is expected to have harmful consequences, such as the emission of greenhouse gases known to be the main drivers of climate change. ${ }^{[1-5]}$ For such reason, concerns are raised for the development of clean and renewable derivatives and energy sources. ${ }^{[6-8]}$ Among the possible renewable energy sources, biomass, and especially lignocellulosic biomass, presents the unique potential of providing liquid biofuels that can replace fossil fuels. ${ }^{[1,9,10]}$ Thermochemical pretreatment of this biomass followed by hydrodeoxygenation reactions yield HDO-oils, that are further mixed with vacuum gas oils (VGO) and proceeded into a fluid catalytic cracking unit (FCC) in order to produce bio-hydrocarbons which still contain some phenol type molecules (0.5 wt.\% to $7 \mathrm{wt} . \%) .{ }^{[3,11-20]}$ Recently, the harmful effects generated by phenol molecules during the combustion of synthetic biofuels were confirmed, e.g. toxic exhaust emissions. These phenol molecules have to be removed in order to obtain ultra clean biofuels. ${ }^{[21,22]}$

Among the various purification processes, adsorption is a low-energy consuming process that allows selective removal of impurities and their further valorization after desorption. ${ }^{[23,24]}$ Due to their relatively low cost, good thermal stability, shape selectivity (pore diameter and aperture) as well as their ability of easily exchanging extra-framework cations, zeolite materials have found many applications in adsorption and catalytic processes. ${ }^{[25-33]}$ Low aluminum loaded zeolites (BEA with $\mathrm{Si} / \mathrm{Al}=\infty$ ) were found to be the most efficient ones for the removal of phenol in wastewater, mainly because of the competitive adsorption of water molecules on zeolite acid sites. ${ }^{[34-36]}$ Recently, faujasite (FAU)-type zeolites were used for the selective adsorption of phenol from alkane solutions, with a high adsorption capacity and a good regeneration ability. ${ }^{[24,37]}$ However, the adsorption performance decreased in presence of competitive adsorbates such as toluene. ${ }^{[38]}$ Therefore, understanding the interactions of phenol and toluene on zeolitic acid sites will help in designing an adsorbent that allows the selective purification of phenol molecules from an aromatic rich hydrocarbon mixture. These findings are leading us to undertake experiments over faujasite-type zeolites exchanged with proton and sodium cations ( $\mathrm{HY}$ and NaY zeolites; Si/Al = 2.5). The effect of the counter cation type on the adsorption modes of phenol and toluene will be investigated with the aim to select the 
cation type that enhances the selective adsorption of phenol. In that sense, in-situ IR spectroscopy is a powerful technique for investigating the interaction modes of adsorbates on zeolite active sites. ${ }^{[39,40]}$ The combination of experiments and predictive calculations for IR spectra can be critical for the allocation of the spectra related to the adsorption modes of

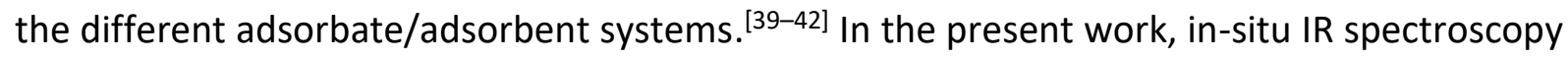
experiments have been combined with periodic DFT in order to assign the vibrational frequencies of the different adsorption modes of phenol and toluene over proton and sodium exchanged zeolites. The interaction energy of the most stable adsorbed configuration of phenol and toluene have been compared for the two zeolites with the purpose to select the most suitable cation-type for achieving the selective removal of phenol from synthetic biofuel feed (isooctane +1 wt.\% phenol +1 wt.\% n-nonane +40 wt.\% toluene).

The paper starts with describing the experimental and computational techniques used for assessing the vibrational modes of phenol and toluene. Then, the different adsorption modes of toluene and phenol over Lewis cation sites $\mathrm{Na}+$ ( $\mathrm{NaY}$ zeolite), and Brønsted acid sites (HY zeolite) were identified and subsequently assigned using gas phase infrared adsorption (FT-IR) analysis complemented with DFT calculations. Finally, zeolites selectivity towards phenol adsorption from synthetic biofuel feeds (containing up to $40 \mathrm{wt}$.\% toluene) has been assessed by gas-phase FT-IR and liquid flow adsorption measurements.

\section{Experimental Section}

\section{Characterization of the adsorbents}

$\mathrm{HY}$ and NaY zeolites with a Si/Al ratio of $\sim 2.5$ were supplied by Union Carbide. The chemical composition of these zeolites was checked by inductively coupled plasma (ICP) connected with optical emission spectroscopy using a Varian ICP-OES 720-ES. Their textural properties were characterized by nitrogen adsorption isotherms at 77K using gas adsorption system ASAP 2020 (Micrometrics) for a relative pressure (P/Po) between 0.05 and 1. Total surface are values were determined using Langmuir model, while the pore volume values and external surface areas were determined by the t-plot method (Fig. SI.1). X-ray powder diffraction (XRPD) patterns were obtained with a PANalytical X'Pert PRO diffractometer with 
Cu K $\alpha$ radiation $\left(\lambda=0.15418 \mathrm{~nm}, 40 \mathrm{~mA}, 45 \mathrm{kV}\right.$, the step size of $0.02^{\circ}$ and a scan speed of $\left.1^{\circ} \cdot \mathrm{min}^{-1}\right)$. The degree of crystallinity of the zeolite fraction can be calculated by comparing the sum of the areas of the four most intense Bragg diffraction peaks at $2 \theta$ of $20.4^{\circ}, 23.7^{\circ}$, $27.1^{\circ}$, and $31.4^{\circ}$ of the considered sample with the sum of the same peak areas of the $\mathrm{NaY}$ zeolite that is considered as a fully crystalline zeolite. ${ }^{[43]}$ Chemical and textural properties of the two studied zeolites are gathered in Table 1. Both zeolites present similar Al amount in the framework as shown by the similar values of Si/AI ratios given by ICP analysis. The XRPD patterns show a full crystalline phase over these two zeolites with compared intensities and absence of amorphous phase. High crystallinity values and low external surface areas in both samples confirm to the absence of defects in these zeolite structures. The two materials also present similar a total pore volume that is mainly formed from micropores.

Table 1 - Chemical and textural properties of the studied adsorbents

\begin{tabular}{lccccccc}
\hline \multirow{2}{*}{ Zeolites } & $\begin{array}{c}\text { Si/Al } \\
\text { (At. ratio) }\end{array}$ & $\begin{array}{c}\text { Crystallinity } \\
\text { (\%) }\end{array}$ & Surface area & External surface & \multicolumn{2}{c}{ Pore volume $\left(\mathrm{cm}^{3} \cdot \mathrm{g}^{-1}\right)$} \\
\cline { 7 - 9 } & 2.5 & 100 & $\left(\mathrm{~m}^{2} \cdot \mathrm{g}^{-1}\right)$ & area $\left(\mathrm{m}^{2} \cdot \mathrm{g}^{-1}\right)$ & Total & micro & meso \\
\hline $\mathrm{NaY}$ & 2.5 & 97 & 1015 & 14 & 0.39 & 0.36 & 0.03 \\
$\mathrm{HY}$ & 2.5 & 1063 & 49 & 0.39 & 0.36 & 0.03 \\
\hline
\end{tabular}

\section{Adsorption experiments}

\section{IR gas phase adsorption and co-adsorption experiments}

Gas phase adsorption and co-adsorption experiments of phenol (with/without toluene) over $\mathrm{NaY}$ and HY zeolites were performed in an in-situ infrared setup. The setup is devised in two parts connected by a valve: the first (V1) where the adsorbates can be introduced and the second (V2) where the adsorbents are holed. The volume of V2 is estimated at twice that of V1. Each zeolite sample was pressed into a self-supported wafer (10-15mg, precisely weighted) with a surface of $2 \mathrm{~cm}^{2}$ under a pressure of $10^{7} \mathrm{~Pa}$. Prior to adsorption measurements, sample wafers were thermally activated under secondary vacuum $\left(10^{-4} \mathrm{~Pa}\right)$ at $623 \mathrm{~K}$ for 4 hours (heating rate of $1 \mathrm{~K} \cdot \mathrm{min}^{-1}$ between $298 \mathrm{~K}$ and $623 \mathrm{~K}$ ), and then cooled down to $298 \mathrm{~K}\left(\sim 10 \mathrm{~K} \cdot \mathrm{min}^{-1}\right)$. A spectrum of the activated sample was acquired after the activation, using a Thermo Fischer 6700 FT-IR spectrophotometer equipped with an MCT detector. 64 scans were accumulated for each measurement with a resolution of $4 \mathrm{~cm}^{-1}$. For 
single molecule adsorption measurements, the valve connecting V1 and V2 was opened and vapor pressures of toluene $(1060 \mathrm{~Pa})$ or phenol $(20 \mathrm{~Pa})$ were introduced on the wafer at 298K. The procedure was repeated until an equilibrium state was reached (negligible fluctuation of the intensities of the bands of the adsorbates). For toluene-phenol coadsorption experiments, after the thermal activation, vapor pressure of toluene (1060 Pa) was introduced until reaching the equilibrium state. Using a vacuum pump and the valve connecting V1 and V2, the toluene pressure on the cell was reduced in order to reach a pressure of $530 \mathrm{~Pa}$ in V2, and a full evacuation in V1. Vapor pressure of phenol (20 Pa) was then introduced to V1 and the valve connecting V1 and V2 was opened. By estimating the relation between the volume of the two parts (V2 $=2 \times \mathrm{V} 1)$, the mol ratio of phenol:toluene was considered equal to 1:53. After reaching the equilibrium state (almost 10-15 minutes), an evacuation of few seconds at $298 \mathrm{~K}$ and a spectrum was collected. All spectra were analyzed by calculating the difference between spectrum after toluene and/or phenol adsorption minus spectrum after the thermal activation. All reported spectra were normalized to a disc constant mass of $5 \mathrm{mg} \cdot \mathrm{cm}^{-2}$ of dried catalyst.

\section{Liquid phase co-adsorption experiments}

Phenol and toluene co-adsorption experiments were performed under flow conditions. The liquid solution containing phenol (Aldrich, 99.5\% purity) was obtained by dissolving $7.0 \mathrm{~g}$ (1 wt.\%) of phenol into $1.0 \mathrm{~L}$ solution of isooctane (Aldrich, $99+\%$ purity), $1 \mathrm{wt}$. \% of $\mathrm{n}$-nonane (Aldrich, 99\% purity) and various concentrations of toluene 0, 1, 10, 40 wt. \% (Aldrich, $99.5+\%$ purity). The amount of phenol and toluene in the solution were chosen taking into consideration the quantity of these two molecules in biofuels after FCC treatment. Adsorption experiments were performed at $298 \mathrm{~K}$ and atmospheric pressure. For all measurements, adsorbents were in-situ activated at $623 \mathrm{~K}$ for 4 hours under argon flow to remove adsorbed water from the pores. Adsorption tests were performed in a glass column of $300 \mathrm{~mm}$ length and $6 \mathrm{~mm}$ internal diameter. $500 \mathrm{mg}$ of zeolite sieves, granulated between 200 and $400 \mu \mathrm{m}$, were packed in the glass column giving a bed volume of 2 to $3 \mathrm{~cm}^{3}$. The liquid solutions containing phenol were fed into the column in a rate of $1 \mathrm{ml}^{\mathrm{min}} \mathrm{min}^{-1}$ using a Gilson pump. The solution was collected periodically and analyzed by a Shimadzu 2010 gas chromatograph equipped with a CP-sil 5CB capillary column $(30 \mathrm{~m})$, a flame ionization detector and nitrogen as carrier gas and using the n-nonane as internal standard. Results 
were plotted as breakthrough curves and the amount of adsorbed phenol per gram of each solid was calculated using the following equation (Eq.1):

$$
q=\frac{C_{0} \cdot D \cdot t_{R}}{m_{a d s}}
$$

where $q$ is the amount of adsorbed phenol per gram of solid $\left(\mathrm{mmol} . \mathrm{g}^{-1}\right), \mathrm{C}_{0}$ is the initial phenol concentration ( $\left.\mathrm{mmol}^{-\mathrm{L}^{-1}}\right), \mathrm{D}$ is the flow rate of the charge containing phenol (L.min $\left.{ }^{-1}\right)$, $m_{\text {ads }}$ is the mass of zeolite $(g)$, and $t_{R}$ is the retention time $(\min )$ when the ratio of $C_{t} / C_{0}$ is equal to 0.5 .

\section{Computational methods}

Periodic DFT calculations of the adsorption of phenol and toluene in $\mathrm{HY}$ and $\mathrm{NaY}$ zeolites is performed using the Vienna Ab initio Simulation Package (VASP). ${ }^{[44]}$ Here, we have used the PBE functional, ${ }^{[45]}$ and the projector augmented plane wave (PAW) method. ${ }^{[46,47]}$ The plane wave cutoff energy is defined as $450 \mathrm{eV}$. The Gaussian smearing was set at $0.1 \mathrm{eV}$. Sampling of the Brillouin zone was limited to the Г-point. The Kohn-Sham equations have been iteratively solved until the energy difference between the cycles becomes lower than $10^{-6}$ eV. Previous investigations ${ }^{[37,48-51]}$ have demonstrated the need to consider van der Waals $(v d W)$ interactions to accurately describe the adsorption of molecules in zeolites, Herein, we have used the very recent $\mathrm{FI} / \mathrm{MDB}$ dispersive correction method. ${ }^{[52]} \mathrm{As}$ in the original MDB method, ${ }^{[53,54]}$ the $\mathrm{Fl} / \mathrm{MDB}$ oversees a simple pairwise correction taking into account the many-body interactions while taking fully account for the ionicity of atoms. ${ }^{[52,55]}$ In this paper, The adsorption energy is defined as the sum of the energy of the empty zeolite and the energy of the isolated molecule in the gas phase minus the energy of the FAU with the adsorbed molecules. A positive value is corresponding to an exothermic process.

To simulate infrared spectra, we have used the density-functional perturbation theory (DFPT), ${ }^{[56-58]}$ which allows to get infrared intensities and frequencies. Indeed, in the dipolar approximation, the intensity of the infrared active modes can be determined as the product of the Born effective charges $Z_{\alpha \beta}^{*}=\partial P_{\beta} / \partial R_{\alpha}$ (the first derivative of the polarization $P_{\beta}$ with respect to the ionic coordinates) and the eigenvectors of the vibrational eigenstates $\mathrm{e}_{\beta}(\mathrm{l})$ as follows (Eq.2) where the sum is on all the atoms of the system: ${ }^{[57,58]}$

$$
I(\omega)=\sum_{\alpha}\left[\sum_{1} \sum_{\beta} Z_{\alpha \beta}^{*}(l) e_{\beta}(l)\right]^{2}
$$

Using the relaxed structures for the adsorption modes, we have performed IR spectra simulations of the IR spectra. In the dipolar approximation, the intensity of ith normal mode 
of vibration at a frequency $\omega_{i}$, is proportional to the square of the change of dipole moment associated with the atomic motion along the eigenvector $\mathbf{e}_{i}$ of that mode (Eq.3): ${ }^{[57,58]}$

$$
I_{i} \propto\left|\frac{\partial \mathbf{P}}{\partial \mathbf{R}} \cdot \mathbf{e}_{i}\right|^{2}=\sum_{\alpha}\left[\sum_{l} \sum_{\beta} Z_{\alpha \beta}^{*}(l) e_{i, \beta}(l)\right]^{2}
$$

Where, $e_{i, \beta}(l)$ is the displacement of /th-atom in the eigenvector of the ith normal mode and $Z_{\alpha \beta}^{*}(I)=\partial P_{\alpha} / \partial R_{B}(I)$ is the Born effective charge of the $l$ th atom. We obtained the quantities in Eq.3 by employing the density-functional perturbation theory (DFPT) implemented in VASP package. ${ }^{[59]}$ This method has been proved to accurately reproduce IR experimental spectra. ${ }^{[57,60]}$

\section{Structural model}

The faujasite structure (FAU) is described in supporting information (Fig. SI.2). ${ }^{[61-64]}$ In this paper, we considered two faujasite structures, $\mathrm{NaY}$ and $\mathrm{HY}$, where Si/Al ratio $=2.5$. According to the known experimental cation distribution, ${ }^{[65]}$ we constructed the $\mathrm{NaY}$ structure by substituting $14 \mathrm{Si}$ atoms for $14 \mathrm{Al}$ atoms, allowing us to add $14 \mathrm{Na}$ atoms in different locations: 8 in site II (supercage), 2 in site I (D6R cage) and 4 in the site I' (sodalite cage) (

Fig. 1). The lattice parameters obtained after a fully optimization of our structure were $a=17.55 \AA, b=17.47 \AA$ and $c=17.69 \AA\left(\alpha=\beta=\gamma=60^{\circ}\right)$, and the corresponding cell volume was equal to $3840.43 \AA^{3}$. HY $(\mathrm{Si} / \mathrm{Al}=2.5)$ was represented by the model previously described by Sastre et al. ${ }^{[66]}$ which was built from the comparison between IR spectroscopy and periodic DFT to mimic a HY zeolite under realistic experimental conditions.

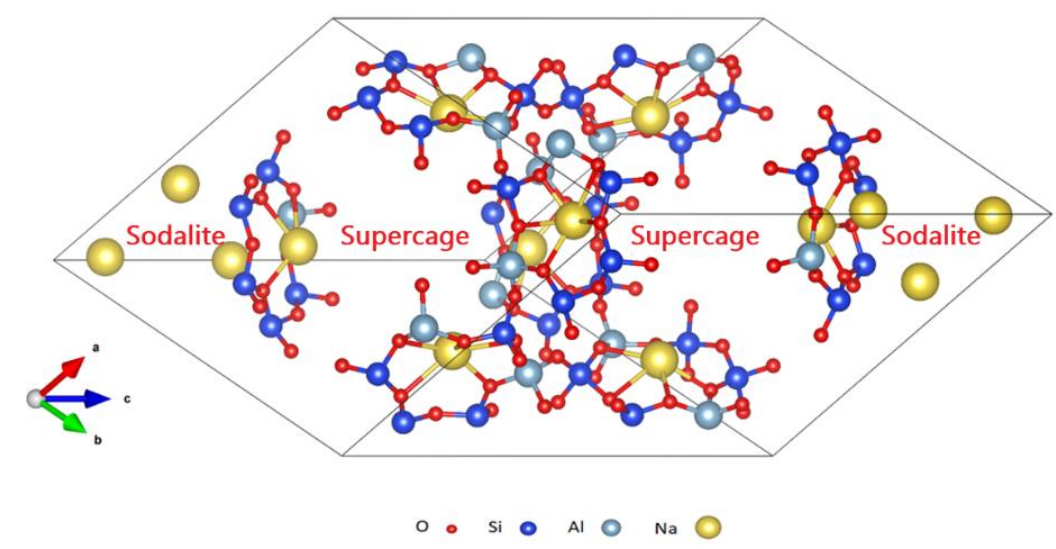

Fig. 1 - Periodic model of a NaY primitive cell showing different cages and cation distribution. 


\section{Results and Discussion}

\section{Adsorption modes: theoretical prediction and spectral vibration analysis}

In this section, we have investigated by modeling tools the adsorption of toluene and phenol on $\mathrm{HY}$ and NaY zeolites. To reach the most stable configurations, we have performed DFT calculations taking into account the recent dispersive correction method FI/MDB. The predicted spectral vibrations for each molecule were compared to experimental measurements performed using an in-situ FT-IR cell.

\section{Vibrational frequencies of the interaction modes of toluene}

The DFPT measurements for toluene adsorption were performed over the described faujasite model ( $\mathrm{Si} / \mathrm{Al}=2.5$ ) owning $\mathrm{Na}^{+}$or $\mathrm{H}^{+}$as compensator charge cations. Over $\mathrm{NaY}$, the most stable configuration of after our DFT calculations was identified as an interaction of the aromatic ring of the toluene with the $\mathrm{Na}^{+}$cation of the $\mathrm{Y}$ zeolite (Fig. 2), which is in line with earlier theoretical investigations performed in zeolites. ${ }^{[67]}$ For such interaction mode, named $\pi$-interaction, the distance between the aromatic ring and the $\mathrm{Na}^{+}$cation was $2.48 \AA$ and the interaction energy corresponds to $158.7 \mathrm{~kJ} / \mathrm{mol}$. This preferential $\pi$-interaction mode of toluene over $\mathrm{NaY}$ was previously reported over $\mathrm{Na}-\mathrm{FAU}$ with higher $\mathrm{Si} / \mathrm{Al}$ ratio $(\mathrm{Si} / \mathrm{Al}=47) .{ }^{[37]}$ Despite the similarity in the adsorption mode, the interaction energy over the high aluminum loaded $\mathrm{NaY}(2.5)$ zeolite was found to be $64.3 \mathrm{~kJ} / \mathrm{mol}$ higher than in the one reported over Na-FAU(47). ${ }^{[37]}$ This can be due to the presence of the Al-OH-Si group in higher amount in the NaY model, which enhances the strength of interactions between the zeolite and toluene molecules, since the total interaction energy increases with the amount of protonated sites in the faujasite. Over the HY zeolite model, toluene was preferentially adsorbed between the two supercages of the zeolite model (Fig. 2). This particular configuration was found to be the most stable with a corresponding adsorption energy of $54.7 \mathrm{~kJ} / \mathrm{mol}$, which was lower than the one of toluene with $\mathrm{NaY}$ zeolite $(158.7 \mathrm{~kJ} / \mathrm{mol})$. These findings highlight a higher affinity of sodium-exchanged zeolites for toluene adsorption. 


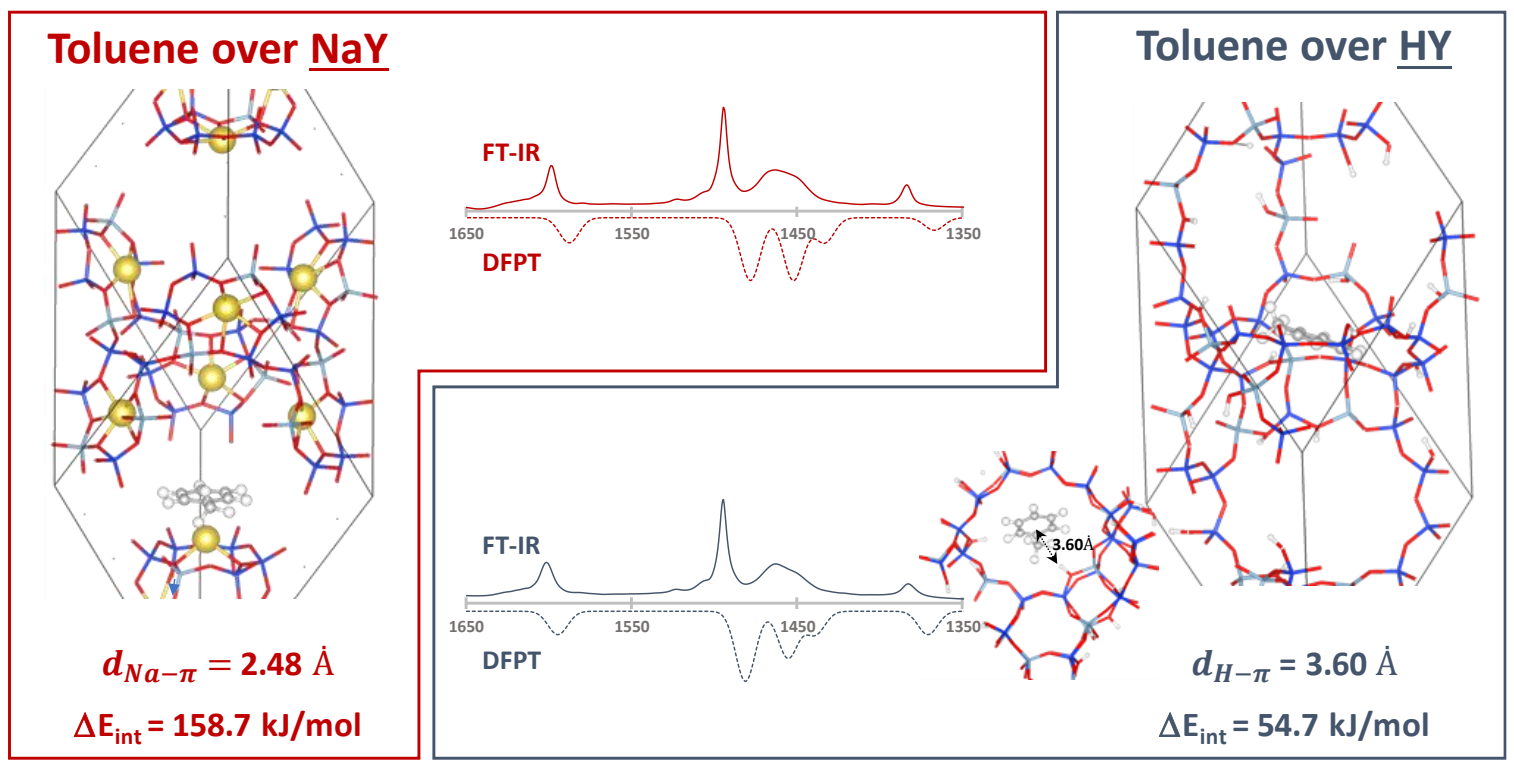

Fig. 2 - The adsorption modes, the experimental (FT-IR) and the predicted (DFPT) vibrational frequencies of the most stable configurations of toluene over $\mathrm{NaY}$ (left hand side) and HY (right hand side). The difference between the peak positions of experimental IR spectra of toluene adsorption over $\mathrm{HY}$ and NaY zeolites is not very pronounced to be seen in this Figure, for better copmparison see Table2. For the sake of clarity, a zoom on the 12MR ring between two supercages of a primitive faujasite unit cell is displayed for HY zeolite. Legend: blue $(\mathrm{Si})$, red $(\mathrm{O})$, sky blue $(\mathrm{Al})$, white $(\mathrm{H})$, gray $(\mathrm{C})$, and yellow $(\mathrm{Na})$.

The difference between the adsorption modes of toluene will raise variations in the vibrational frequencies, thus by using IR spectroscopy we will be able to detect the difference between both adsorption modes. DFPT method was used to predict the vibrational frequencies of the most stable configuration of toluene over each zeolite and the results were confirmed by experimental toluene adsorption measurements followed by FTIR spectroscopy. The use of the DFPT method allows to access a theoretical analysis of the spectral vibrations to interpret macroscopic properties, such as the adsorption of the organic molecule into porous materials. Herein, we only studied the most stable configuration of each molecule adsorbed in the two solids. The corresponding vibrational frequencies for toluene adsorption and gas phase toluene were studied in the region of $1300-1600 \mathrm{~cm}^{-1}$, and results are shown in Table 2.

First, gas phase toluene bands were extracted from Omnic software database while the observed bands in the region of $1300-1600 \mathrm{~cm}^{-1}$ are shown in Table 2. The stretching vibrations of carbon bonds of the aromatic ring of toluene $v\left(\mathrm{CC}_{\text {ring }}\right)$ were observed in the range of 1604 and $1457 \mathrm{~cm}^{-1}$, the bending vibration of the $\mathrm{C}-\mathrm{H}$ bonds $\delta\left(\mathrm{CH}_{\text {ring }}\right)$ of the aromatic ring was identified at $1495 \mathrm{~cm}^{-1}$, the deformation vibration of the methyl group 
$\delta\left(\mathrm{CH}_{\mathrm{Me}}\right)$ was depicted at $1466 \mathrm{~cm}^{-1}$, while the band at $1380 \mathrm{~cm}^{-1}$ corresponds to a combination of $v\left(\mathrm{CC}_{\text {ring }}\right)$ and $\delta\left(\mathrm{CH}_{\mathrm{Me}}\right)$ vibrations. ${ }^{[68,69]}$ For toluene adsorption over $\mathrm{NaY}$ zeolite, experimental (from FT-IR) measurements and DFPT calculations present the same order of magnitudes. However, the vibrational bands obtained by FT-IR were in better agreement with the toluene vibration bands in gas phase, since red-shift of 11 to $16 \mathrm{~cm}^{-1}$ was observed over all the computed bands (Table 2). The adsorption mode of toluene over $\mathrm{NaY}$ involves an interaction between the aromatic ring of toluene and the zeolitic $\mathrm{Na}^{+}$cation (Fig. $2)$, thus, the $v\left(\mathrm{CC}_{\text {ring }}\right)$ vibrations show red-shifts of $5 \mathrm{~cm}^{-1}$ and $9 \mathrm{~cm}^{-1}$ for the bands at 1604 $\mathrm{cm}^{-1}$ and $1457 \mathrm{~cm}^{-1}$, respectively (Table 2$)$. The shift was less pronounced on $v\left(\mathrm{CH}_{\text {ring }}\right)$, $\delta\left(\mathrm{CH}_{\mathrm{Me}}\right)$ and $v\left(\mathrm{CC}_{\text {ring }}\right)+\delta\left(\mathrm{CH}_{\mathrm{Me}}\right)$ vibrations, due to their indirect involvement in the proposed adsorption mode. Regarding toluene adsorption over HY zeolite, the most stable adsorption mode does not involve any interaction of the molecule with the acid sites. Thus, the shift values were only $-2 \mathrm{~cm}^{-1}$ and $-4 \mathrm{~cm}^{-1}$ for the two $v\left(C_{\text {ring }}\right)$ vibrations at $1604 \mathrm{~cm}^{-1}$ and 1457 $\mathrm{cm}^{-1}$, and less than $4 \mathrm{~cm}^{-1}$ for all other vibrational modes (Table 2). In summary, the higher affinity of $\mathrm{NaY}$ zeolite towards toluene adsorption can be explained by the stable configuration obtained via the interaction of the aromatic ring with the $\mathrm{Na}^{+}$cation. This adsorption mode can be highlighted by the bands at 1599 and $1448 \mathrm{~cm}^{-1}$ that correspond to $v\left(\mathrm{CC}_{\text {ring }}\right)$ vibrations.

Table 2 - Predicted (DFPT) and experimental (FT-IR) vibrational frequencies (in $\mathrm{cm}^{-1}$ ) of gas phase toluene and adsorbed toluene over $\mathrm{NaY}$ and $\mathrm{HY}$ zeolites in the wavenumber region $1350-1650 \mathrm{~cm}^{-1}$.

\begin{tabular}{l|l|ll|ll}
\hline & \multicolumn{2}{|l|l|l|l}{ Toluene } & \multicolumn{2}{l}{ a } & \multicolumn{2}{|l}{ Toluene over NaY } & \multicolumn{2}{l}{ over HY } \\
\hline Vibrational mode & Gas phase & DFPT & FT-IR & DFPT & FT-IR \\
\hline$v\left(\mathrm{CC}_{\text {ring }}\right)$ & 1604 & 1588 & $1599(-5)$ & 1595 & $1602(-2)$ \\
$\delta\left(\mathrm{CH}_{\text {ring }}\right)$ & 1495 & 1478 & $1494(-1)$ & 1480 & $1495(0)$ \\
$\delta\left(\mathrm{CH}_{\text {Me }}\right)$ & 1466 (Asym. def.) & 1452 & $1464(-2)$ & 1455 & $1465(-1)$ \\
$v\left(\mathrm{CC}_{\text {ring }}\right)$ & 1457 & 1434 & $1448(-9)$ & 1440 & $1453(-4)$ \\
$v\left(\mathrm{CC}_{\text {ring }}\right)+\delta\left(\mathrm{CH}_{\text {Me }}\right)$ & 1380 (Sym. def.) & 1367 & $1383(+3)$ & 1371 & $1383(+3)$ \\
\hline
\end{tabular}

${ }^{a}$ Frequencies extracted from the database of Omnic software; $v\left(\mathrm{CC}_{\text {ring }}\right)$ : aromatic $\mathrm{C}-\mathrm{C}$ stretching; $\delta\left(\mathrm{CH}_{\text {ring }}\right)$ : aromatic $\mathrm{C}-\mathrm{H}$ bending; $\delta\left(\mathrm{CH}_{\mathrm{Me}}\right)$ : methyl $\mathrm{C}-\mathrm{H}$ bending; Asym. def.: asymmetric deformation; Sym. def.: symmetric deformation. Values between the brackets correspond to the difference in the wavenumber frequencies between gas phase toluene bands and adsorbed toluene bands depicted by FT-IR. 


\section{Vibrational frequencies of phenol interaction modes}

As for toluene, different configurations were observed for phenol when changing the counter cation type. An overlook on the gas phase phenol bands, extracted from Omnic database, in the region of $1400-1650 \mathrm{~cm}^{-1}$ shows the stretching vibrations of the carbon bonds of the aromatic ring $v\left(\mathrm{CC}_{\text {ring }}\right)$ at 1606,1596 and $1473 \mathrm{~cm}^{-1} \cdot{ }^{[70,71]} \mathrm{A}$ combination band of $v\left(\mathrm{CC}_{\text {ring }}\right)+\delta\left(\mathrm{CH}_{\text {ring }}\right)$ was also observed at $1497 \mathrm{~cm}^{-1} \cdot{ }^{[70,72]}$ The region $1300-1400 \mathrm{~cm}^{-1}$, where the $\delta\left(\mathrm{OH}_{\text {phenol }}\right)$ vibration can be observed, was not investigated due to the difficult interpretation of the broad aspect of this band as shown in by FT-IR measurement (Fig. SI.3). Over NaY zeolite, the most stable adsorption mode of phenol represented by a $\pi$-interaction of the aromatic ring of phenol with the sodium cation, in a distance of $2.43 \AA$ (Fig. 3). The total interaction energy was about $101.8 \mathrm{~kJ} / \mathrm{mol}$, being slightly higher than the interaction energy of phenol found over a Na-FAU(47) with lower aluminum loading. ${ }^{[37]}$ In comparison with toluene adsorption, the difference between the interaction energies ( $\Delta \mathrm{E}_{\text {int }}$ (toluene) $=158.7$ $\mathrm{kJ} / \mathrm{mol}>\Delta \mathrm{E}_{\text {int }}($ phenol) $=101.8 \mathrm{~kJ} / \mathrm{mol})$ emphasizes a preferential adsorption of toluene, in regards to phenol, over the NaY zeolite, by a difference of $56.9 \mathrm{~kJ} / \mathrm{mol}$. DFPT computed vibrations of phenol over $\mathrm{NaY}$ and the experimental ones measured by FT-IR are shown in Table 3. As for toluene, the vibrational bands obtained by FT-IR were in high agreement with the phenol vibration bands in gas phase, since a red-shift of 4 to $14 \mathrm{~cm}^{-1}$ was observed on all the computed bands. As can be expected from the adsorption configuration, all the bands including the $v\left(\mathrm{CC}_{\text {ring }}\right)$ vibrational mode were red-shifted by -5 and $-7 \mathrm{~cm}^{-1}$ in comparison to gas phase phenol bands. Thus, the $v\left(\mathrm{CC}_{\text {ring }}\right)$ vibrations of the interaction mode of phenol over NaY zeolite appears experimentally at 1599, 1591, 1492 and $1468 \mathrm{~cm}^{-1}$. The band observed at $1498 \mathrm{~cm}^{-1}$ is referred to the $\delta\left(\mathrm{CH}_{\text {ring }}\right)$ vibration that corresponds to the combination $v\left(\mathrm{CC}_{\text {ring }}\right)+\delta\left(\mathrm{CH}_{\text {ring }}\right)$ bands at $1497 \mathrm{~cm}^{-1}$ in the gas phase phenol spectrum. Due to that evoked adsorption mode, $v\left(\mathrm{CC}_{\text {ring }}\right)$ vibration shows a shift value of $-5 \mathrm{~cm}^{-1}$ and thus was observed at $1492 \mathrm{~cm}^{-1}$, while $\delta\left(\mathrm{CH}_{\text {ring }}\right)$ vibration was slightly affect and thus remains at $1497 \mathrm{~cm}^{-1}$. 


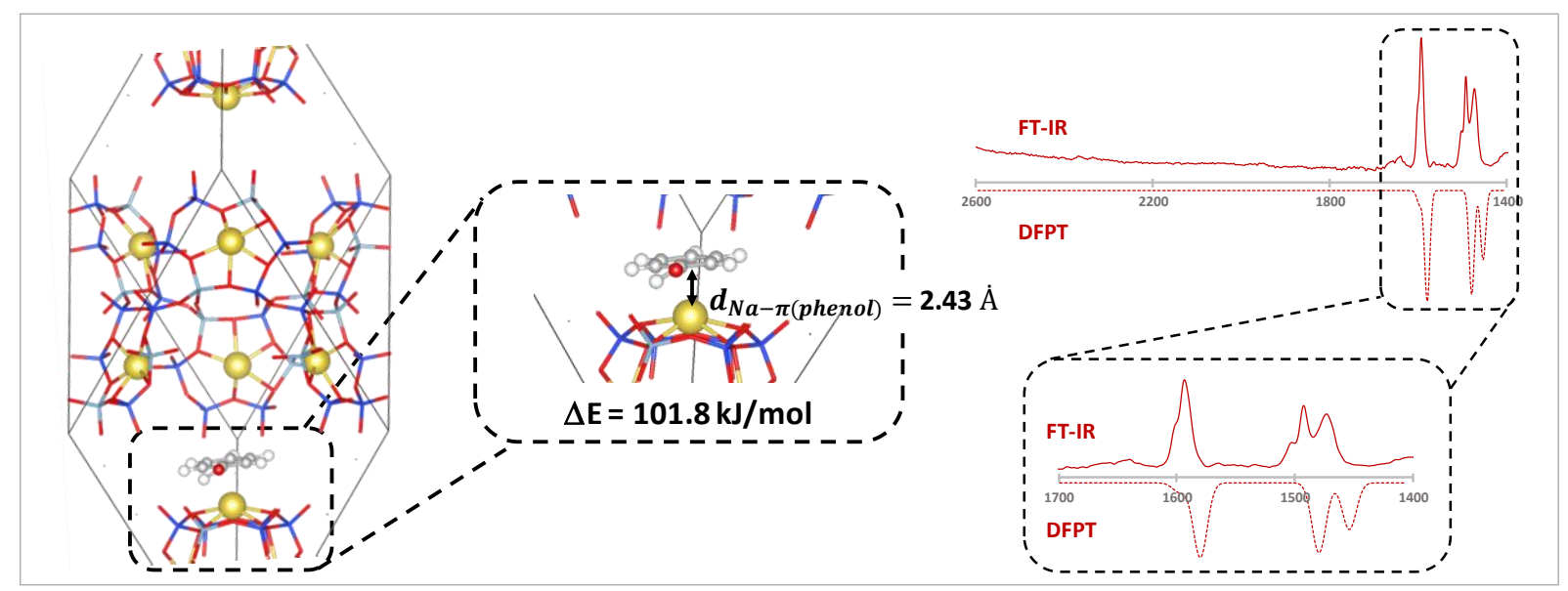

Fig. 3 - The adsorption modes, the predicted (via DFPT) and the experimental (via FT-IR) vibrational frequencies of the most stable configurations of phenol over NaY. Legend: blue node $(\mathrm{Si})$, red node/sphere $(\mathrm{O})$, sky blue node $(\mathrm{Al})$, white sphere $(\mathrm{H})$, gray sphere $(\mathrm{C})$, and yellow sphere $(\mathrm{Na})$.

Over HY zeolite, two configurations were observed for phenol adsorption: (1) the first, namely $\pi$-interaction, takes place between the aromatic ring of phenol and the acid site of the zeolite, with a distance of $2.45 \AA$, while (2) the second, namely O-interaction, corresponds to an interaction of the oxygen atom of phenol and the acid site of the zeolite, with a distance of $1.99 \AA$ (Fig. 4). The O-interaction was found to be the most stable configuration with an interaction energy of $115.4 \mathrm{~kJ} / \mathrm{mol}$, which is $53.5 \mathrm{~kJ} / \mathrm{mol}$ higher than the interaction energy via the $\pi$-interaction mode (Table 3 ). In comparison with toluene adsorption, high affinity towards phenol adsorption is observed over the HY zeolite, with a difference of $60.7 \mathrm{~kJ} / \mathrm{mol}$.

Table 3 - Predicted (DFPT) and experimental (FT-IR) vibrational frequencies (in $\mathrm{cm}^{-1}$ ) of gas phase phenol and phenol adsorbed over $\mathrm{NaY}$ and $\mathrm{HY}$ zeolites in the wavenumber region $1300-2600 \mathrm{~cm}^{-1}$.

\begin{tabular}{l|l|ll|lll}
\hline & Phenol $^{\mathrm{a}}$ & \multicolumn{4}{l|}{ Phenol over NaY } & \multicolumn{3}{l}{ Phenol over HY } \\
\hline Vibrational mode & Gas phase & $\begin{array}{l}\text { DFPT } \\
(\pi \text {-inter })\end{array}$ & FT-IR & $\begin{array}{l}\text { DFPT } \\
(\pi \text {-inter })\end{array}$ & $\begin{array}{l}\text { DFPT } \\
\text { (O-inter })\end{array}$ & FT-IR \\
\hline$v\left(\mathrm{OH}_{\text {HY }}\right)$ & - & - & - & - & 2563 & $2459-2938$ \\
$v\left(\mathrm{CC}_{\text {ring }}\right)$ & 1606 & 1595 & $1599(-7)$ & 1595 & 1601 & $1603(-3)$ \\
$v\left(\mathrm{CC}_{\text {ring }}\right)$ & 1596 & 1581 & $1591(-5)$ & 1577 & 1585 & $1596(0)$ \\
$v\left(\mathrm{CC}_{\text {ring }}\right)+\delta\left(\mathrm{CH}_{\text {ring }}\right)$ & 1497 & 1480 & $1492(-5)$ & 1479 & 1481 & $1492(-5)$ \\
& & & $1498(+1)$ & & & $1499(+2)$ \\
$v\left(\mathrm{CC}_{\text {ring }}\right)$ & 1473 & 1454 & $1468(-5)$ & 1448 & 1465 & $1474(+1)$ \\
\hline
\end{tabular}

a Frequencies extracted from the database of Omnic software; $v\left(\mathrm{OH}_{\mathrm{HY}}\right)$ : zeolite $\mathrm{O}-\mathrm{H}$ stretching; $v\left(\mathrm{CC}_{\text {ring }}\right)$ : aromatic $\mathrm{C}-\mathrm{C}$ stretching; $\delta\left(\mathrm{CH}_{\text {ring }}\right)$ : aromatic $\mathrm{C}-\mathrm{H}$ bending. Values between the brackets correspond to the 
difference in the wavenumber frequencies between gas phase toluene bands and adsorbed toluene bands depicted by FT-IR.

The theoretical study of the vibrational frequencies of each of the two adsorption modes of phenol over HY zeolite was performed by DFPT. The results are reported in Table 3 and show the phenol adsorption band via the aromatic ring at $1595 v\left(\mathrm{CC}_{\text {ring }}\right), 1577 v\left(\mathrm{CC}_{\text {ring }}\right), 1498$ $v\left(\mathrm{CC}_{\text {ring }}\right)+\delta\left(\mathrm{CH}_{\text {ring }}\right)$ and $1448 \mathrm{~cm}^{-1} v\left(\mathrm{CC}_{\text {ring }}\right)$. These vibrations were similar to those showed for phenol adsorbed over $\mathrm{NaY}$ zeolite via the same adsorption mode. For the most stable configuration, O-interaction, bands were observed at $1601 v\left(\mathrm{CC}_{\text {ring }}\right), 1585 v\left(\mathrm{CC}_{\text {ring }}\right), 1481$ $v\left(\mathrm{CC}_{\text {ring }}\right)+\delta\left(\mathrm{CH}_{\text {ring }}\right)$ and $1465 \mathrm{~cm}^{-1} v\left(\mathrm{CC}_{\text {ring }}\right)$. In addition, a specific band was depicted at 2563 $\mathrm{cm}^{-1}$ that refers to the zeolitic $\mathrm{OH}$ stretching $v\left(\mathrm{OH}_{\mathrm{HY}}\right)$. Experiment measurements for phenol adsorption over HY zeolite followed by FT-IR spectroscopy show a small influence on the $v\left(\mathrm{CC}_{\text {ring }}\right)$ and $\delta\left(\mathrm{CH}_{\text {ring }}\right)$ vibrational bands of phenol (bands observed at 1603, 1596, 1491, 1499 and $1474 \mathrm{~cm}^{-1}$ ). Additionally, two broad bands were observed in the high wavenumbers region (2200-3400 $\left.\mathrm{cm}^{-1}\right)$ : the first at $2938 \mathrm{~cm}^{-1}$ that corresponds to a $v\left(\mathrm{OH}_{\mathrm{HY}}\right)$ vibration and the second at $2459 \mathrm{~cm}^{-1}$ with its shoulder at $2531 \mathrm{~cm}^{-1}$ that refer to $2 \delta\left(\mathrm{OH}_{\mathrm{HY}}\right.$ ) vibrations (Fig. 4). These bands were shifted to low wavenumbers due to a strong Fermi resonance. ${ }^{[73,74]}$ The additional broad band observed around $3200 \mathrm{~cm}^{-1}$ was attributed to $v\left(\mathrm{OH}_{\text {phenol }}\right)$ vibrations of hydrogen bounded phenol-phenol at high loading. Thus, by correlating the peak positions on the experimental vibrational frequencies and the zeolitic $\mathrm{OH}$ stretching $v\left(\mathrm{OH}_{\mathrm{HY}}\right)$, it is confirmed that phenol adsorption via O-interaction is the configuration adopted over $\mathrm{HY}$ zeolite. The presence of this adsorption mode of phenol suggests that HY zeolite can be a suitable material for performing the selective removal of phenol for hydrocarbon mixtures including aromatic compounds, such as toluene. 


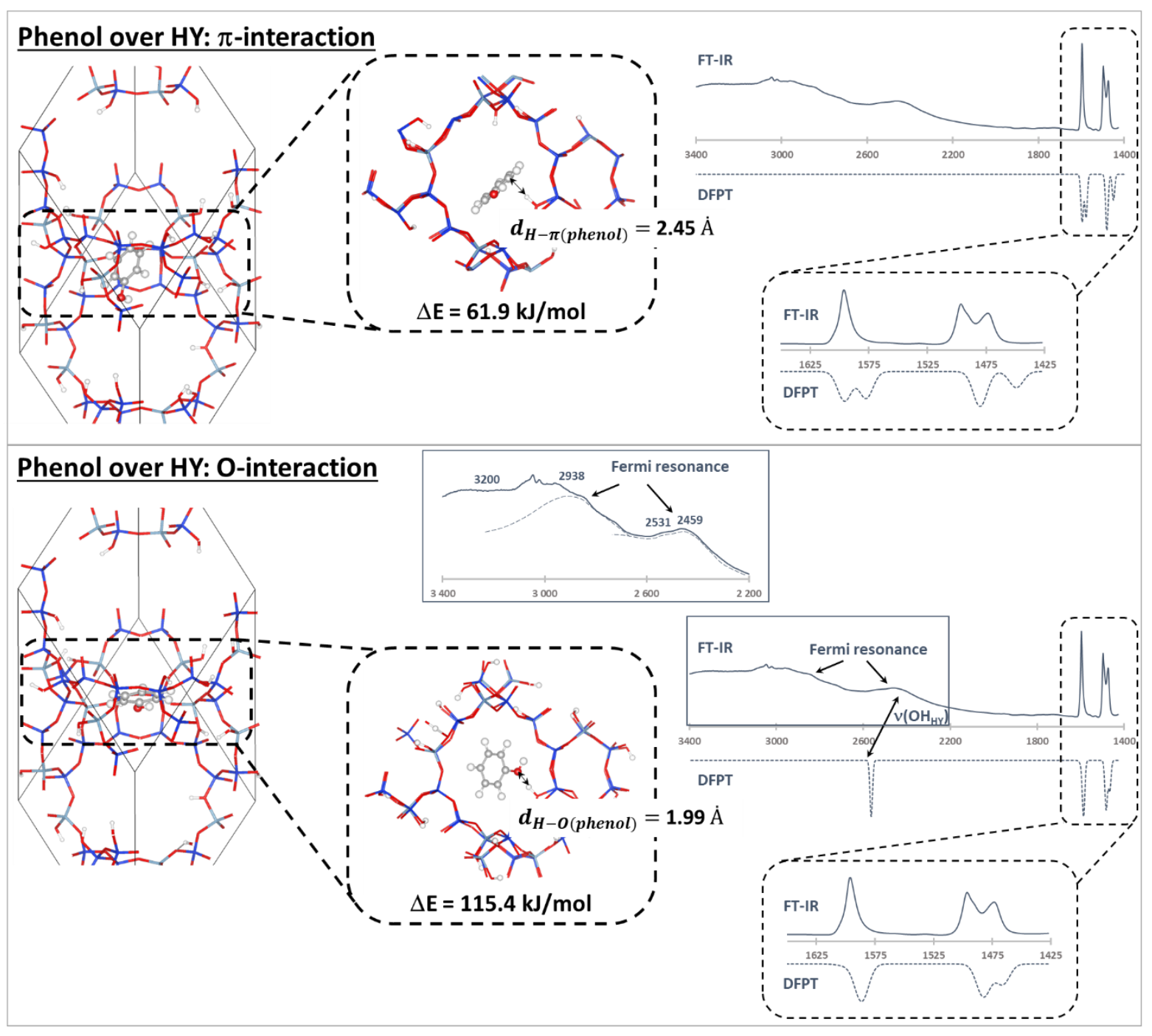

Fig. 4 - The different adsorption modes of phenol over HY zeolite with their respective interaction energies and predicted vibrational frequencies via DFPT (negative scale). For comparison, the FT-IR phenol adsorption spectrum in the region of $1400-3400 \mathrm{~cm}^{-1}$ is shown (positive scale). Legend: blue node (Si), red node/sphere (O), sky blue node (Al), white sphene $(H)$, and gray sphere $(C)$.

\section{Selective adsorption of phenol in presence of toluene}

In this section, the selective adsorption of phenol over $\mathrm{NaY}$ and $\mathrm{HY}$ zeolites in the presence of different amounts of toluene will be investigated using gas phase in-situ FT-IR setup and liquid phase flow adsorption setup. Selectivity measurements in gas phase consist on following the vibrational bands of adsorbed phenol molecules after adding a gas mixture of phenol and toluene over $\mathrm{HY}$ and $\mathrm{NaY}$ zeolites. While, selectivity measurements in liquid phase rely on the analysis of the breakthrough curves obtained after flowing mixtures of phenol in hydrocarbons solution containing different loading of toluene (1 - 40 wt.\%) on a 
standing bed of adsorbent. The selectivity factor of each zeolite will be determined by analyzing the ratios of adsorbed phenol over toluene.

\section{Co-adsorption in gas phase}

The protocol described in the experimental section for toluene-phenol gas phase coadsorption was used. After establishing a toluene equilibrium of $1060 \mathrm{~Pa}$ in the IR cell, spectra of the solids, NaY and HY wafers, were recorded and reported in Fig. 5. The equilibrium state was considered to be reached when the intensity of the toluene bands was stable in regard to the addition of gas phase toluene molecules. While keeping the toluene pressure in the IR cell, an equilibrium pressure of phenol (20 Pa) was added and spectra were recorded until reaching the equilibrium state (Fig. 5). The molar composition of the mixture (mol ratio phenol:toluene $=1: 53$ ) was chosen by considering the ratio between phenol and aromatic compounds in biofuels after FCC treatment (mol ratio of phenolics:aromatics $\approx 1: 45) .{ }^{[22,23]}$ After saturation with toluene, bands corresponding to adsorbed toluene species appeared in the spectra recorded over $\mathrm{NaY}$ (Fig. 5 dashed red line) and HY (Fig. 5 dashed blue line) zeolites. After adding phenol vapors in mixture with toluene over $\mathrm{NaY}$ zeolite, phenol vibrational bands at almost 1470 and $1590 \mathrm{~cm}^{-1}$ appears in minor amount (Fig. 5 solid red line). However, the phenol molecules added in the gas mixture did not displace the toluene molecules already adsorbed over $\mathrm{NaY}$ zeolite, even after further doses. On the other hand, once phenol was added over HY zeolite (Fig. 5 solid blue line), toluene molecules were displaced until that no more specific bands referred to toluene appear in the spectrum. These findings highlight an important selectivity aspect of HY zeolite towards phenol in the presence of toluene, which supports its use for selective removal of phenol traces from biofuels.

$\mathrm{NaY2.5}$

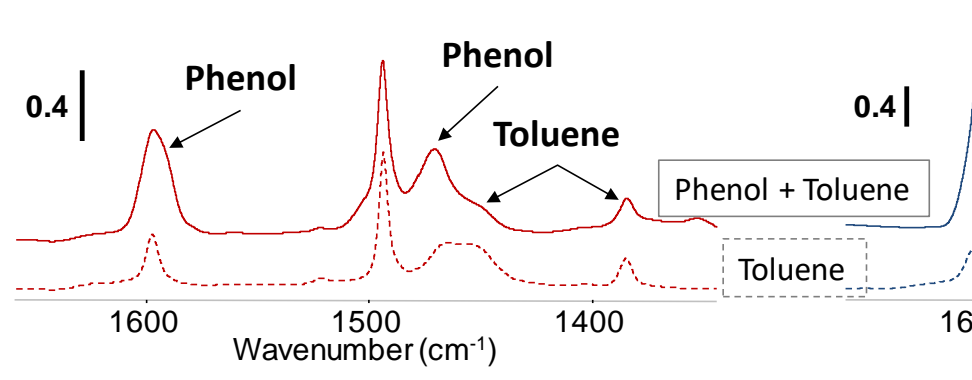

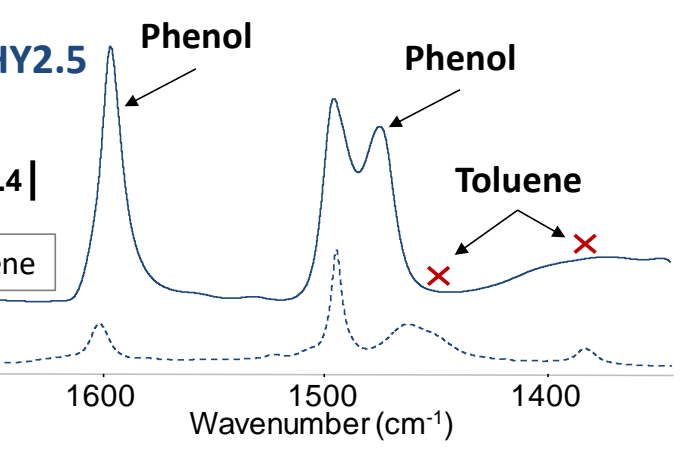

Fig. 5 - FT-IR equilibrium spectra of phenol-toluene co-adsorption in gas phase over $\mathrm{NaY}$ and HY zeolites. Dotted lines correspond to toluene adsorption spectra, solid line refer to 
the spectra recorded after adding phenol over the adsorbents saturated with toluene.

\section{Co-adsorption in liquid phase followed by breakthrough experiments}

To study the adsorption selectivity of the two zeolites in liquid phase experiments, mixtures of isooctane, $\mathrm{n}$-nonane, $1 \mathrm{wt} . \%$ of phenol containing various concentrations of toluene $(0,1$, 10 and $40 \mathrm{wt} . \%)$ were prepared and flowed over a packed bed of the adsorbent in a dynamic adsorption system. In absence of toluene, the maximum phenol uptakes of $\mathrm{NaY}$ and $\mathrm{HY}$ zeolites were identified. Fig. 6 shows a higher adsorption capacity over HY zeolite (2.1 $\mathrm{mmol} / \mathrm{g})$ in comparison to $\mathrm{NaY}(1.2 \mathrm{mmol} / \mathrm{g})$, which can be due to the phenol-phenol rearrangement inside the supercages of the $\mathrm{HY}$ zeolite at high loading. ${ }^{[24]}$ By taking into consideration the presence of $4.2 \times 10^{20}$ supercages per gram of zeolite, the maximum adsorption capacities correspond to 3 and 2 phenol molecules per supercage of $\mathrm{HY}$ and $\mathrm{NaY}$ zeolites, respectively. In addition to its lowest adsorption capacity, the phenol uptake of $\mathrm{NaY}$ zeolite was strongly affected by the presence of toluene in the mixture. In presence of 1 wt.\% toluene, different behaviors were observed by each zeolite. By following the amount of phenol and toluene at the outlet of the adsorption bed, breakthrough curves were plotted as shown in Fig. 6A and Fig. SI.4. The analysis of the breakthrough curves was divided into 3 regions. During the first minutes (region 1), both toluene and phenol molecules were filling the free volume in the zeolite pores (Fig. 6A). After few minutes, the elution of toluene starts over both zeolites prior to the phenol elution. After the total elution of toluene molecules, the toluene concentrations in the effluent surpass temporarily that in the feed, indicating a roll-up effect of toluene. Indeed, the adsorbed toluene molecules are displaced and replaced by phenol. The ratio adsorbed/displaced (A/D) toluene was calculated for both zeolites and results show an A/D value of almost 75 over NaY zeolite, which indicates a high affinity towards toluene adsorption since less than $2 \%$ of the adsorbed toluene molecules were displaced. In contrast, HY zeolite shows preferential adsorption of phenol since all adsorbed toluene molecules were displaced $(A / D \approx 1.0)$. These results are in consistent with the theoretical results where phenol molecules have shown stronger interaction energies with $\mathrm{HY}$ zeolite than toluene, see Fig. 2 and Fig. $4\left(\Delta \mathrm{E}_{\text {int }}(\mathrm{phenol} / \mathrm{HY})=115.4 \mathrm{~kJ} / \mathrm{mol}>\Delta \mathrm{E}_{\text {int }}\right.$ (toluene/HY $)=$ $54.7 \mathrm{~kJ} / \mathrm{mol})$. Over the sodium cation, toluene molecules have shown stronger interaction energies than phenol, which explains the reason why they remain adsorbed over the $\mathrm{NaY}$ 
zeolite. The reason behind that phenol molecules were keep being adsorbed was not fully understood, it can be due to a specific adsorption configuration adopted by phenol molecules at high loading in the supercage of the zeolite as shown for pure phenol adsorption over HY(2.5) and H-USY(40) zeolites in a previous work, ${ }^{[24]}$ or to a specific phenoltoluene interaction mode during the adsorption process. NVT Monte Carlo simulations can be performed to understand the latter observation. In the last region of the breakthrough curves (region 3) the maximum adsorption capacities were reached over the adsorbents.

Co-adsorption measurements were repeated with different toluene loadings in the mixtures (10 and 40 wt.\%) and the corresponding breakthrough curves are shown in Fig. SI.4. The amount of adsorbed phenol and toluene at the end of each adsorption cycle were calculated and compared to the amount of adsorbed phenol in absence of toluene (Fig. 6B). The presence of toluene loadings in the mixture leads to decrease the phenol adsorption capacity of $\mathrm{NaY}$ zeolite. The presence of $1 \mathrm{wt} . \%$ toluene decreased the amount of adsorbed phenol by $38 \%(0.81 \mathrm{mmol} / \mathrm{g}$ instead of $1.23 \mathrm{mmol} / \mathrm{g})$, the difference of $0.42 \mathrm{mmol} / \mathrm{g}$ corresponds to adsorbed toluene over this sample. Inversely, the adsorption capacity of HY zeolite towards phenol was maintained in the presence of $1 \mathrm{wt} . \%$ of toluene. At high toluene loadings, the inherent effect of toluene on the phenol adsorption over NaY zeolite was even more pronounced, since the amount of adsorbed phenol decreased by $58 \%$ and $83 \%$ in presence of 10 and 40 wt.\% of toluene, respectively (Fig. 6B). Over HY zeolite, the amount of adsorbed phenol was intact, even in the presence of $40 \mathrm{wt} . \%$ of toluene, which confirms the high selectivity of the protonic zeolites in the selective removal of phenol from hydrocarbons containing aromatic components.

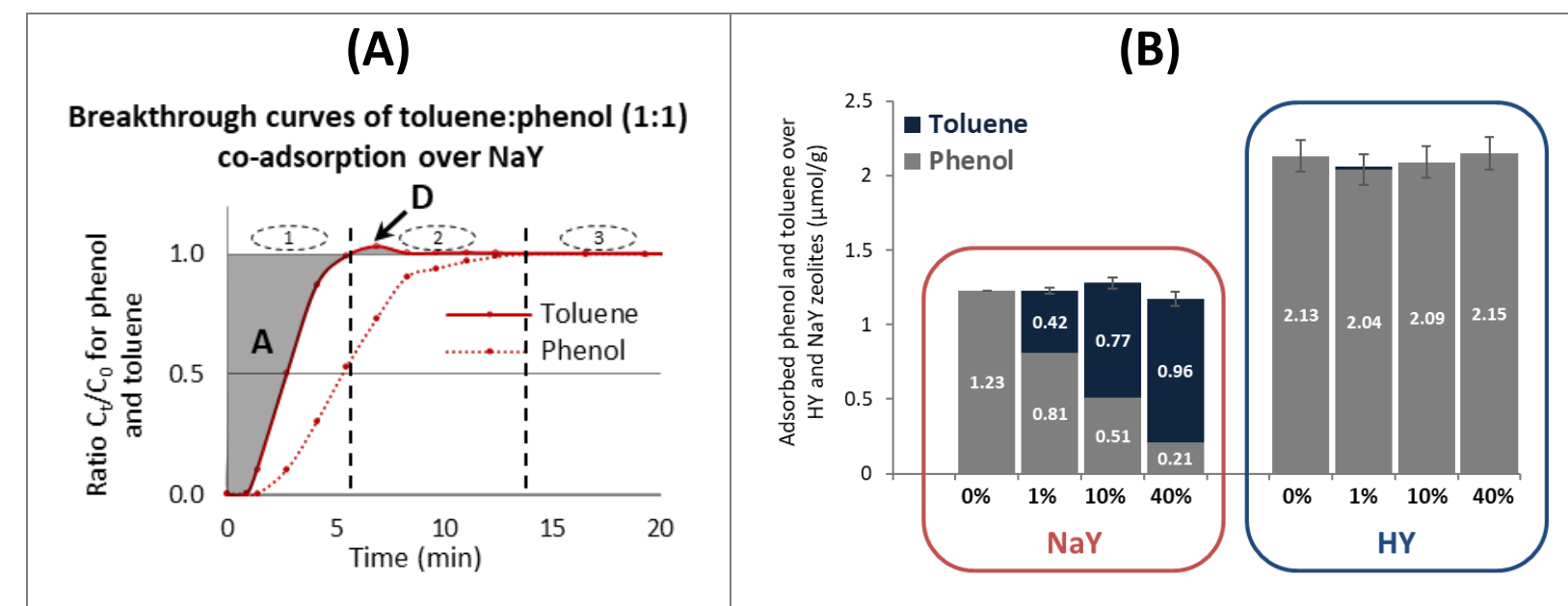

Fig. 6 - (A) Breakthrough curve of phenol:toluene (1:1) co-adsorption over NaY zeolite, 


\section{Conclusion}

We have investigated experimental IR measurements and DFT for building a selective purification process for phenol removal from aromatic rich hydrocarbon mixtures. Especially, we have identified the adsorption modes and interaction energies of toluene and phenol over $\mathrm{NaY}$ and $\mathrm{HY}$ zeolites. We have also investigated the influence of these interactions on the vibrational frequencies of IR spectra. Toluene adsorbed over $\mathrm{NaY}$ zeolite via $\pi-$ interactions with an interaction energy of $158.7 \mathrm{~kJ} / \mathrm{mol}$. This adsorption mode involved an interaction of the toluene aromatic ring with the zeolitic $\mathrm{Na}^{+}$cation that was depicted by a red-shift of the $v\left(\mathrm{CC}_{\text {ring }}\right)$ vibration bands observed at $1599 \mathrm{~cm}^{-1}\left(-5 \mathrm{~cm}^{-1}\right)$ and $1448 \mathrm{~cm}^{-1}(-9$ $\mathrm{cm}^{-1}$ ). Over HY zeolite, toluene preferentially adsorbed between the two supercages of the zeolite model, involving minor fluctuations on the overall IR spectrum. The interaction energy $(54.7 \mathrm{~kJ} / \mathrm{mol})$ of toluene over HY zeolite was lower than over NaY zeolite, showing a higher affinity of sodium-exchanged zeolites than proton-exchanged zeolites for toluene.

The most stable adsorption configuration for phenol over NaY zeolite corresponds to the $\pi-$ interaction of the phenol aromatic ring with the $\mathrm{Na}^{+}$site. The adsorption configuration involves a red-shift of $5 \mathrm{~cm}^{-1}$ over all the bands including the $v\left(\mathrm{CC}_{\text {ring }}\right)$ vibrational mode. Thus, relative vibrational bands of this mode appear experimentally at $1599 v\left(C_{\text {ring }}\right), 1591$ $v\left(\mathrm{CC}_{\text {ring }}\right), 1492 v\left(\mathrm{CC}_{\text {ring }}\right)$ and $1468 v\left(\mathrm{CC}_{\text {ring }}\right) \mathrm{cm}^{-1}$. The interaction energy of phenol with $\mathrm{NaY}$ zeolite shows a value of $101.8 \mathrm{~kJ} / \mathrm{mol}$, which is about $56.9 \mathrm{~kJ} / \mathrm{mol}$ lower than the interaction energy of toluene over this zeolite. These findings emphasize a bad selectivity of NaY zeolite towards phenol adsorption in the presence of toluene. Over HY zeolite, the most stable adsorption configuration of phenol corresponds to an interaction of the oxygen atom of phenol and the acid site of the zeolite (O-interaction). Specific vibrations of this adsorption mode were observed at $2563 v\left(\mathrm{OH}_{\mathrm{HY}}\right), 1601 v\left(\mathrm{CC}_{\text {ring }}\right), 1585 v\left(\mathrm{CC}_{\text {ring }}\right), 1481 v\left(\mathrm{CC}_{\text {ring }}\right)+\delta\left(\mathrm{CH}_{\text {ring }}\right)$ and $1465 v\left(\mathrm{CC}_{\text {ring }}\right) \mathrm{cm}^{-1}$. Owing this adsorption mode and its high interaction energy 115.4 $\mathrm{kJ} / \mathrm{mol}$ (about $60.7 \mathrm{~kJ} / \mathrm{mol}$ higher than for the interaction of toluene over HY), HY zeolite could be a suitable material for selectively removing phenol from hydrocarbon mixtures comprising toluene. 
Finally, these findings were confirmed by competitive gas (FT-IR) and liquid (flow adsorption process) phase adsorption experiments on a synthetic biofuel feed. Results confirmed a higher adsorption capacity of HY zeolite than $\mathrm{NaY}$ zeolite for phenol. In addition, the presence of different amounts of toluene in the mixture dramatically affected the adsorption capacity of NaY zeolite for phenol, while no effect was observed for HY zeolite. With a novel combination of gas phase FT-IR adsorption, DFT and DFPT calculations, and liquid phase adsorption, the present work underlined the superiority of $\mathrm{HY}$ zeolite over $\mathrm{NaY}$ for reaching an efficient selective capture of phenol from biofuels.

\section{Acknowledgments}

The authors acknowledge the French Agence Nationale de la Recherche (ANR), through the program Investissements d'Avenir (ANR-10-LABX-09-01), LabEX EMC3 and FEDER for the financial support to the BIOCAR project. We thank the PMMS (Pôle Messin de Modélisation et de Simulation) and GENCI-CCRT/CINES (Grant No. x2019- A0060810169) for providing us computer time. We also acknowledge financial support through the COMETE project (COnception in silico de Matériaux pour l'EnvironnemenT et l'Energie) co-funded by the European Union under the program "FEDER-FSE Lorraine et Massif des Vosges 2014-2020". 


\section{References}

[1] G. Fogassy, C. Lorentz, G. Toussaint, N. Thegarid, Y. Schuurman, C. Mirodatos, Environ. Prog. Sustain. Energy 2013, 32, 377-383.

[2] R. Sun, A. Kann, H. Hartmann, A. Besmehn, P. J. C. Hausoul, R. Palkovits, ChemSusChem 2019, 12, 3278-3285.

[3] S. Darda, T. Papalas, A. Zabaniotou, J. Clean. Prod. 2019, 208, 575-588.

[4] M. Gholizadeh, X. Hu, Q. Liu, Renew. Sustain. Energy Rev. 2019, 114, 109313.

[5] L. Grajciar, J. Čejka, A. Zukal, C. Otero Areán, G. Turnes Palomino, P. Nachtigall, ChemSusChem 2012, 5, 2011-2022.

[6] I. Khalil, G. Quintens, T. Junkers, M. Dusselier, Green Chem. 2020, 22, 1517-1541.

[7] M. N. Nabi, M. M. Rahman, M. A. Islam, F. M. Hossain, P. Brooks, W. N. Rowlands, J. Tulloch, Z. D. Ristovski, R. J. Brown, Energy Convers. Manag. 2015, 96, 588-598.

[8] X. Jin, B. Yin, Q. Xia, T. Fang, J. Shen, L. Kuang, C. Yang, ChemSusChem 2019, 12, 71-92.

[9] J. C. Serrano-Ruiz, J. A. Dumesic, Energy Environ. Sci. 2011, 4, 83-99.

[10] M. Bertero, G. de la Puente, U. Sedran, Fuel 2012, 95, 263-271.

[11] M. Bertero, G. de la Puente, U. Sedran, Fuel 2012, 95, 263-271.

[12] C. Bouvier, Y. Romero, F. Richard, S. Brunet, Green Chem. 2011, 13, 2441-2451.

[13] G. W. Huber, S. Iborra, A. Corma, Chem. Rev. 2006, 106, 4044-4098.

[14] Z. Zhang, Q. Wang, P. Tripathi, C. U. P. Jr, Green Chem. 2011, 13, 940-949.

[15] I. Graça, A. Fernandes, J. M. Lopes, M. F. Ribeiro, S. Laforge, P. Magnoux, F. Ramôa Ribeiro, Fuel 2011, 90, 467-476.

[16] F. de Miguel Mercader, M. J. Groeneveld, S. R. A. Kersten, N. W. J. Way, C. J. Schaverien, J. A. Hogendoorn, Appl. Catal. B Environ. 2010, 96, 57-66.

[17] H. Kim, N. R. Vinueza, S. S. Kelley, S. Park, Carbon Resour. Convers. 2018, 1, 238-244.

[18] A. de R. Pinho, M. B. B. de Almeida, F. L. Mendes, L. C. Casavechia, M. S. Talmadge, C. M. Kinchin, H. L. Chum, Fuel 2017, 188, 462-473.

[19] A. de R. Pinho, M. B. B. de Almeida, F. L. Mendes, V. L. Ximenes, L. C. Casavechia, Fuel Process. Technol. 2015, 131, 159-166.

[20] M. E. Domine, A. C. van Veen, Y. Schuurman, C. Mirodatos, ChemSusChem 2008, 1, 179-181.

[21] M. N. Nabi, M. M. Rahman, M. A. Islam, F. M. Hossain, P. Brooks, W. N. Rowlands, J. Tulloch, Z. D. Ristovski, R. J. Brown, Energy Convers. Manag. 2015, 96, 588-598.

[22] I. Khalil, Elimination par adsorption sélective du phénol pour la purification des biocarburants de 2ème génération. Chimie Organique. Normandie Université (FR), 2018.

[23] K. Thomas, I. Khalil, F. Maugé, Proc. 8 Th Serbian-Croat.-Slov. Symp. Zeolites 2019, 4144.

[24] I. Khalil, H. Jabraoui, G. Maurin, S. Lebègue, M. Badawi, K. Thomas, F. Maugé, J. Phys. Chem. C 2018, 122, 26419-26429.

[25] S. Chibani, I. Medlej, S. Lebègue, J. G. Ángyán, L. Cantrel, M. Badawi, ChemPhysChem 2017, 18, 1642-1652.

[26] S. Chibani, M. Chebbi, S. Lebègue, L. Cantrel, M. Badawi, Phys. Chem. Chem. Phys. 2016, 18, 25574-25581.

[27] Q. Ke, T. Sun, H. Cheng, X. Wei, Y. Guo, S. Zhao, S. Zeng, S. Wang, Ind. Eng. Chem. Res. 2018, 57, 16763-16771.

[28] Q. Ke, T. Sun, X. Wei, Y. Guo, S. Xu, S. Wang, Chem. Eng. J. 2019, 359, 344-353. 
[29] H. Jabraoui, G. Maurin, S. Lebègue, I. Khalil, K. Thomas, F. Maugé, M. Badawi, Bull Am Phys Soc 2019, 64 (2), V31.005.

[30] X. Wu, M. Qiu, X. Chen, G. Yu, X. Yu, C. Yang, J. Sun, Z. Liu, Y. Sun, New J. Chem. 2018, 42, 111-117.

[31] C. Zhou, J. Shi, W. Zhou, K. Cheng, Q. Zhang, J. Kang, Y. Wang, ACS Catal. 2020, 10, 302310.

[32] K. Góra-Marek, A. E. Palomares, A. Glanowska, K. Sadowska, J. Datka, Microporous Mesoporous Mater. 2012, 162, 175-180.

[33] A. Philippaerts, S. Goossens, W. Vermandel, M. Tromp, S. Turner, J. Geboers, G. Van Tendeloo, P. A. Jacobs, B. F. Sels, ChemSusChem 2011, 4, 757-767.

[34] M. Khalid, G. Joly, A. Renaud, P. Magnoux, Ind. Eng. Chem. Res. 2004, 43, 5275-5280.

[35] B. Koubaissy, G. Joly, I. Batonneau-Gener, P. Magnoux, Ind. Eng. Chem. Res. 2011, 50, 5705-5713.

[36] B. Van de Voorde, D. Damasceno Borges, F. Vermoortele, R. Wouters, B. Bozbiyik, J. Denayer, F. Taulelle, C. Martineau, C. Serre, G. Maurin, et al., ChemSusChem 2015, 8, 3159-3166.

[37] H. Jabraoui, I. Khalil, S. Lebègue, M. Badawi, Mol. Syst. Des. Eng. 2019, 4, 882-892.

[38] I. Khalil, K. Thomas, H. Jabraoui, P. Bazin, F. Maugé, J. Hazard. Mater. 2020, 384, DOI 10.1016/j.jhazmat.2019.121397.

[39] L. Zavala-Sanchez, I. Khalil, L. Oliviero, J. Paul, F. Maugé, ChemCatChem 2020, Just accepted, DOI 10.1002/cctc.201902053.

[40] I. Khalil, C. M. Celis-Cornejo, K. Thomas, P. Bazin, A. Travert, D. J. Pérez-Martínez, V. G. Baldovino-Medrano, J.-F. Paul, F. Maugé, ChemCatChem 2020, 12, 1095-1108.

[41] M. Chebbi, S. Chibani, J.-F. Paul, L. Cantrel, M. Badawi, Microporous Mesoporous Mater. 2017, 239, 111-122.

[42] S. Chibani, M. Chebbi, S. Lebègue, T. Bučko, M. Badawi, J. Chem. Phys. 2016, 144, $244705-244714$.

[43] R. López-Fonseca, J. I. Gutiérrez-Ortiz, M. A. Gutiérrez-Ortiz, J. R. González-Velasco, J. Catal. 2002, 209, 145-150.

[44] G. Kresse, J. Hafner, Phys. Rev. B 1993, 47, 558-561.

[45] J. P. Perdew, K. Burke, M. Ernzerhof, Phys. Rev. Lett. 1996, 77, 3865-3868.

[46] P. E. Blöchl, Phys. Rev. B 1994, 50, 17953-17979.

[47] G. Kresse, D. Joubert, Phys. Rev. B 1999, 59, 1758-1775.

[48] F. Göltl, A. Grüneis, T. Bučko, J. Hafner, J. Chem. Phys. 2012, 137, 114111.

[49] E. P. Hessou, W. G. Kanhounnon, D. Rocca, H. Monnier, C. Vallières, S. Lebègue, M. Badawi, Theor. Chem. Acc. 2018, 137, 161.

[50] E. P. Hessou, H. Jabraoui, M. T. A. K. Hounguè, J.-B. Mensah, M. Pastore, M. Badawi, Z. Für Krist. - Cryst. Mater. 2019, 234, 469-482.

[51] H. Jabraoui, E. P. Hessou, S. Chibani, L. Cantrel, S. Lebègue, M. Badawi, Appl. Surf. Sci. 2019, 485, 56-63.

[52] T. Gould, S. Lebègue, J. G. Ángyán, T. Bučko, J. Chem. Theory Comput. 2016, 12, 59205930.

[53] A. Tkatchenko, R. A. DiStasio, R. Car, M. Scheffler, Phys. Rev. Lett. 2012, 108, 236402.

[54] T. Bučko, S. Lebègue, T. Gould, J. G. Ángyán, J. Phys. Condens. Matter 2016, 28, 045201.

[55] T. Bučko, S. Lebègue, J. Hafner, J. G. Ángyán, J. Chem. Theory Comput. 2013, 9, 42934299.

[56] S. Baroni, S. de Gironcoli, A. Dal Corso, P. Giannozzi, Rev. Mod. Phys. 2001, 73, 515-562. 
[57] D. Karhanek, Self-Assembled Monolayers Studied by Density-Functional Theory, phd, uniwien, 2010.

[58] D. Karhánek, T. Bučko, J. Hafner, J. Phys. Condens. Matter 2010, 22, 265006.

[59] M. Gajdoš, K. Hummer, G. Kresse, J. Furthmüller, F. Bechstedt, Phys. Rev. B 2006, 73, 045112.

[60] P. Giannozzi, S. Baroni, J. Chem. Phys. 1994, 100, 8537-8539.

[61] S. Buttefey, A. Boutin, C. Mellot-Draznieks, A. H. Fuchs, J. Phys. Chem. B 2001, 105, 9569-9575.

[62] E. Dempsey, G. H. Kuehl, D. H. Olson, J. Phys. Chem. 1969, 73, 387-390.

[63] W. J. Mortier, Compilation Of Extra Framework Sites In Zeolites, Westbury Ho., Guildford, Surrey, UK, 1982.

[64] F. Porcher, M. Souhassou, Y. Dusausoy, C. Lecomte, Eur. J. Mineral. 1999, 11, 333-344.

[65] T. Frising, P. Leflaive, Microporous Mesoporous Mater. 2008, 114, 27-63.

[66] G. Sastre, N. Katada, K. Suzuki, M. Niwa, J. Phys. Chem. C 2008, 112, 19293-19301.

[67] F. H. Yang, A. J. Hernandez-Maldonado, R. T. Yang, Sci. Technol. 2005, 39, 1717-1732.

[68] M. Tasumi, T. Urano, M. Nakata, J. Mol. Struct. 1986, 146, 383-396.

[69] A. P. Hitchcock, J. D. Laposa, J. Mol. Spectrosc. 1975, 54, 223-230.

[70] J. C. Evans, Spectrochim. Acta 1960, 16, 1382-1392.

[71] A. Popov, E. Kondratieva, L. Mariey, J. M. Goupil, J. El Fallah, J.-P. Gilson, A. Travert, F. Maugé, J. Catal. 2013, 297, 176-186.

[72] W. Roth, P. Imhof, M. Gerhards, S. Schumm, K. Kleinermanns, Chem. Phys. 2000, 252, 247-256.

[73] R. Osuga, T. Yokoi, J. N. Kondo, Mol. Catal. 2019, 477, 110535.

[74] L. Oliviero, A. Vimont, J.-C. Lavalley, F. Romero Sarria, M. Gaillard, F. Maugé, Phys Chem Chem Phys 2005, 7, 1861-1869. 


\section{Graphical Abstract}

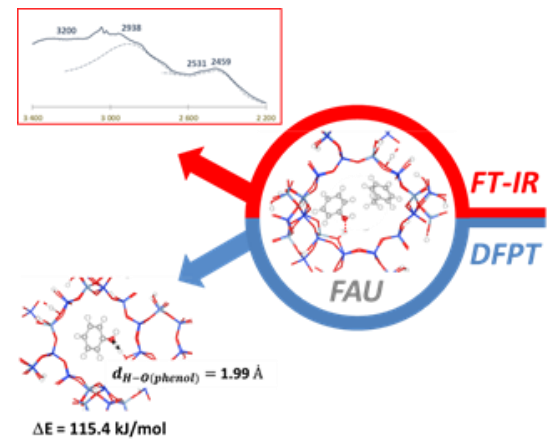

"Theoretical and experimental assessment for the selective removal of phenol from synthetic $2^{\text {nd }}$ generation biofuels. Investigation of the competitive adsorption, identification of the adsorption modes and their relative interaction energies and vibrational frequencies"

Keywords: adsorption, biofuels, zeolite, DFT, FT-IR spectroscopy

\section{Nomenclature}

\begin{tabular}{|ll|}
\hline DFPT & Density-Functional Perturbation Theory \\
DFT & Density Functional Theory \\
FCC & Fluid Catalytic Cracking \\
FT-IR & Fourier Transform Infrared Spectroscopy \\
HDO & Hydrodeoxygenation \\
MCT & Mercury Cadmium Telluride detector \\
PBE & Perdew, Burke and Ernzerhof \\
VASP & Vienna Ab initio Simulation Package \\
VGO & Vacuum Gas Oil \\
\hline
\end{tabular}

